Dicle Tıp Dergisi / Dicle Med J (2019) 46 (4) : 799 - 806

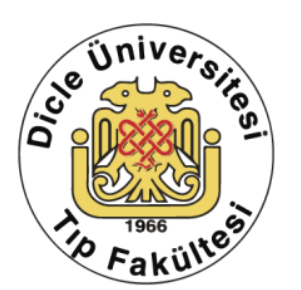

www.diclemedj.org

Özgün Araştırma / Original Article

\title{
Gastroenterit Nedeniyle Yatırılan Pediatrik Hastaların Rotavirüs/Adenovirüs Açısından Değerlendirilmesi
}

\author{
Muhammet Asena1 ${ }^{1}$ Adem Canan², Ünal Öztürk³ ${ }^{3}$ Pınar Aydın Öztürk \\ Ayfer Gözü Pirinççioğlu 5
}

1 Sağlık Bil. Üniversitesi Gazi Yașargil Sağllk Uygulama ve Araștırma Merkezi, Pediatri Bölümü, Diyarbakır, Türkiye, ORCID:0000-0002-0033-8672 2 Sağlık Bil. Üniversitesi Gazi Yaşargil Sağlık Uygulama ve Araştırma Merkezi, Pediatri Bölümü, Diyarbakır, Türkiye, ORCID:0000-0002-5368-6451 3 Sağlık Bil. Üniversitesi Gazi Yașargil Sağlık Uygulama ve Araștırma Merkezi, Nöroloji Bölümü, Diyarbakır, Türkiye, ORCID:0000-0002-8341-5070

4 Sağlık Bil. Üniversitesi Gazi Yaşargil Sağlık Uygulama ve Araştırma Merkezi, Nöroşirurji Bölümü, Diyarbakır, Türkiye, ORCID:0000-0002-7688-7774

5 Dicle Üniversitesi Tıp Fakültesi, Pediatri Bölümü, Diyarbakır, Türkiye, ORCID: 0000-0002-2524-2124

Geliş: 23.08.2019; Revizyon: 07.10.2019; Kabul Tarihi: 22.10.2019

Öz

Amaç: Çocuk sağlı̆̆ alanındaki global iyileşmeye rağmen, 5 yaş altı çocuk ölümlerinin en sık 2. nedenini hala gastroenteritler oluşturmaktadır. Yenidoğan ve küçük çocuklarda ağır gastroenteritin en sık nedeni rotavirüstür. Enterik Adenovirüs ise ikinci en slk viral gastroenterit nedenidir.

$\mathrm{Bu}$ çalışma ile gastroenterit etyolojisi olarak rotavirüs/adenovirüs sıklığının araştırılması, klinik bulgu ve laboratuvar parametrelerine etkisi, yatış süreci üzerine etkisinin diğer gastroenteritlerle karşılaștırılarak değerlendirilmesi ile önlem ve tedavi ile ilgili çalışmalara temel oluşturulması amaçlandı.

Yöntemler: Çalışmamıza hastanemize gastroenterit tanısıyla yatan 353 hasta dahil edilmiştir. Hastaların yaşı, cinsiyeti, ishal sıklığı, rotavirüs veya adenovirüs saptanıp saptanmadığı, klinik bulguları, probiyotik-antibiyotik kullanımı, eşlik eden hastalık varlığı, kaç gün yattığı, yattığı ay, C-reaktif protein düzeyi, hematolojik ve biyokimyasal parametreler retrospektif olarak değerlendirildi. Rotavirüs/adenovirüs antijen pozitifiliği saptanan hastalar rotavirüs/adenovirüs saptanmayan hastalarla (kontrol grubu) istatistiksel olarak karşılaştırıldı.

Bulgular: Hastaların yaş ortalaması 18,8 (1-125) aydı. Yaş grubuna göre diare sıklığına bakıldığında hastaların en sık \%56,9 ile 624 ay arasında olduğu 6-24 ay arası hasta grubunun \%40,8'inde rotavirüs/adenovirüs saptanmış olup bu durum istatistiksel olarak anlamlı bulunmuştur ( $\mathrm{p}=0.03$ ).

Gaita sayısına bakıldığında rotavirüs/adenovirüs saptanan hastaların \%80,6’sında 10 ve üzerinde gaita sayısı saptanmış olup istatiksel olarak anlamlı bulunmuştur. Rotavirüs/adenovirüs saptanan hastalarda iştahsızlı, halsizlik ve dehidratasyon bulgularına kontrol grubuna oranla daha sık rastlandığı görülmektedir.

Sonuç: Çalışma sonuçları göz önüne alındığında rotavirüs/adenovirüse bağlı gastroenteritlerde klinik bulguların daha belirgin olduğu, ancak laboratuvar parametrelerinden anlamlı farklılık olmadığı gözlenmektedir.

Bu nedenle özellikle klinik bulguları daha ağır olan gastroenterit hastalarında viral nedenlerin araştırılması etkin semptomatik tedavi ve gereksiz antibiyoterapiden kaçınılmasını sağlayacaktır.

Anahtar kelimeler: Gastroenterit, rotavirüs, adenovirüs 


\title{
Evaluation of Patients Admitted for Gastroenteritis in Terms of Rotavirus / Adenovirus
}

\begin{abstract}
Objective: Despite the fact of global scale improvements on the field of pediatrics, gastroenteritis is still the second major reason of under 5 years ol children deaths. Rotavirus is the most common reason for gastroenteritis at newborns and little children. Enteric Adenovirus is on the other hand, is the second most common viral reason of gastroenteritis.

This study aims to examine the rotavirus/adenovirus incidences as gastroenteritis etiology, the effect on clinical findings and laboratory parameters, evaluation of the effect on hospitalization period by comparising with other gastroenteritis and becoming a basis for studies about precautions and treatments.

Methods: 353 patients with gastroenteritis diagnosis at our hospital were included in this study. Parameters like age, gender, diarrhea frequency, detection of rotavirus adenovirus, clinical findings, probiotic-antibiotic utilization, existance of any kind of accompanying disease, days of hospitalization, month of hospitalization, C-reactive protein level, hematological and biochemical parameteres were evaluated retrorespectively. The patients with detection of rotavirus/adenovirus antigen existance were compared statistically with the patients doesnt have those antigens (control group).

Results: Age average of the patients was 18.8 (1-125 months) months. When the diarrhea frequency of the patients was considered according to their ages, the most frequent age interval was $6-24$ months with $56.9 \%$ rate, whereas $40.8 \%$ of the patients that are between 6-24 months old had rotavirus/adenovirus antigen detection, which was proved as statistically meaningful $(\mathrm{p}=0.03)$.

When the gaita count was considered, $80.6 \%$ of the patients with rotavirus/adenovirus detection were discovered to have 10 or more gaita count, which was proved to be statistically meaningful.

Findings like loss of apetite, malaise and dehydration were found more frequently when compared to the patients at the control group.

Conclusions: Despite the fact that rotavirus/adenovirus related gastroneteritis clinical findings were more distinct, there was no meaningful difference observed according to laboratory parameters. Therefore, the examination of viral causes among gastroenteritis patients with more severe clinical findings will provide effective symptomatic treatment and refrainment from unnecessary antibiotherapy.
\end{abstract}

Keywords: Gastroenteritis, rotavirus, adenovirus.

\section{GİRIŞ}

Çocuk sağlığı alanındaki global iyileşmeye rağmen, 5 yaş altı çocuk ölümlerinin en sık 2 . nedenini hala gastroenteritler oluşturmaktadır1. Yenidoğan ve küçük çocuklarda ağır gastroenteritin en sık nedeni rotavirüstür2. Rotavirüs kaynaklı gastroenteritler hastane yatışlarının \%36'sindan sorumludur 1 .

Rotavirüs sosyoekonomik koşullarından bağımsız olarak, gelişmiş ve gelişmekte olan ülkelerde benzer sıklıkta görülür. Ancak gelişmiş ülkelerde yüksek morbidite ve ekonomik kayıplarla neden olurken gelişmekte olan ülkelerde yüksek mortalite ile sonuçlanmaktadır ${ }^{2-4}$.

Enterik Adenovirüs, Rotavirüs'ten sonra ikinci en slk viral gastroenterit nedeni olup 0-3 yaş grubunda akut ve uzamış gastroenteritten sorumludur. Enterik Adenovirüs \%5-15 oranında görülür. Dehidratasyon, metabolik asidoz ve laktoz intoleransına neden olabilir ${ }^{5}$.

$\mathrm{Bu}$ çalışma gastroenterit etyolojisi olarak rotavirüs/adenovirüs sıklığının araştırılması, klinik bulgu ve laboratuvar parametrelerine etkisi, yatış süreci üzerine etkisinin diğer gastroenteritlerle karşılaştırılarak değerlendirilmesi ile önlem ve tedavi ile ilgili 
çalışmalara temel oluşturulması amacıyla yapıldı.

\section{YÖNTEMLER}

Çalışmamıza Ocak 2018 - Aralık 2018 tarihleri arasında hastanemize gastroenterit tanısıyla yatan 353 hasta dahil edilmiştir.

Hastaların yaşı, cinsiyeti, ishal sıklığı, rotavirüs veya adenovirüs saptanıp saptanmadığl, klinik bulguları, probiyotik-antibiyotik kullanımı, eşlik eden hastalık varlığı, kaç gün yattığı, yattığı ay, C-reaktif protein (CRP) düzeyi, hematolojik ve biyokimyasal parametreler retrospektif olarak değerlendirildi. Rotavirüs/adenovirüs antijen pozitifiliği saptanan hastalar rotavirüs/adenovirüs saptanmayan hastalarla (kontrol grubu) istatistiksel olarak karşılaştırıldı. (Çalışmamızda Enterik Adenovirüs sıklığı çok az olduğundan etkin randomizasyon olmayacağı düşünülerek tek başına bir grup olarak değil Rotavirüs ile birlikte değerlendirildi.)

Rotavirüs/adenovirüs tanısı dışkıda enzim immünoassay (ELISA) yöntemi ile konuldu.

Istatistiksel Analizler: İstatistiksel yazılım programı SPSS 20 (Statistical Package for the Social Sciences - IBM®, Chicago, IL, USA) kullanıldı. Değişkenlerin normal dağılımı görsel (histogram) ve analitik yöntemler (Kolmogorov-Simirnov test) kullanılarak değerlendirildi. Oransal değişkenlerin istatistiksel analizleri Ki-kare testi ile, bağımsız grupların analizi Student-t testi, iki değişken arasındaki doğrusal ilişki korelasyon analizi ile yapıldı. $\mathrm{p}<0,05$ istatistiksel olarak anlamlı kabul edildi.

Çalışma için hastanemiz etik kurulundan 04.07.2019 tarih 322 sayı numarası ile onay alınmış olup Helsinki Deklarasyonu prensiplerine uyulmuştur.

\section{BULGULAR}

Çalışmaya gastroenterit nedeniyle hastaneye yatırılın 353 hasta dahil edildi. Hastaların 65 $(\% 1,4)$ tanesinde Rotavirüs AP, $7 \quad(\% 2,0)$ tanesinde Enterik Adenovirüs AP saptandı.

Hastaların 151 (\%42,8)'i kız çocuk, 202 $(\% 57,2)$ 'si erkek çocuktu. Rotavirüs/Enterik Adenovirüs antijen pozitifliği (R/A AP) saptanan hastaların $29(\% 40,2)$ 'u kız çocuk, 43 $(\% 59,8)$ 'ü erkek çocuk olup istatistiksel olarak anlamlı bulunmamıștır ( $\mathrm{p}>0.05)$. Aynı zamanda kız çocuklarının \%19,2'sinde, erkek çocuklarının \%21,2'sinde R/A AP saptanmıştır. Yaş ortalaması 18,8 (1-125) aydı. R/A AP olan hastaların yaş ortalaması 13,2 (1-91) aydı. Yaş grubuna göre diare sıklığına bakıldığında hastaların \%20,4'ü 0-6 ay arası, \%56,9'u 6-24 ay arası, \%16,1'i 2-5 yaş arası, \%6,5'i 5 yaş üstü hastalardı. 0-6 ay arası hasta grubunun $\% 27,8$ 'inde, 6-24 ay arası hasta grubunun \%40,8'inde, 2-5 yaş arası hasta grubunun $\% 15,8$ 'inde ve 5 yaş üstü hasta grubunun \%8,7'sinde R/A saptanmış olup bu durum istatistiksel olarak anlamlı bulunmuştur $(\mathrm{p}=0.03)$.

Mevsimsel dağılıma bakıldığında hem R/A AP saptanan grubun hem kontrol grubunun kış aylarında (sırasıyla \%30,5 ve \%28,4) daha sık yatırıldığı ancak istatistiksel olarak anlamlı bulunmadığg görülmüştür.

Gaita sayısına bakıldığında hastaların $\% 11,9$ 'unda 5 ve 5'ten az, \%51,.8'inde 5-10 aralığında, \%36,3'ünde 10 ve üzeri olarak saptanmıştır. R/A saptanan hastalarda gaita sayısı \%19,4'ünde 5-10 aralığında iken $\% 80,6$ 'sında 10 ve üzerinde saptanmıştır. Bu durum istatistiksel olarak anlamlıdır $(\mathrm{p}<0.01)$. Kusma hastaların \%56,4'ünde, iștahsızlı \%45'inde, karın ağrısı \%6,5'inde, ateş \%54,1'inde, halsizlik \%69,7'sinde saptanırken dehidratasyon bulgularına hastaların \%29,2'sinde rastlanmıştır. R/A saptanan hastaların \%58,3'ünde kusma, \%62,5'inde iştahsızlık ( $\mathrm{p}<0.01)$, \%6,9'unda karın ağrısı, 
$\% 59,7$ 'sinde ateş, $\% 86,1$ 'inde halsizlik $(\mathrm{p}<0.01)$ ve $\% 51,3$ 'ünde dehidratasyon $(\mathrm{p}<0.01)$ saptanmıştır. Aynı zamanda dehidratasyon bulguları olan hastaların \%72,9'u 6-24 ay aralığındaydı. Bu sonuçlara bakıldığında R/A AP saptanan hastalarda iştahsızlık, halsizlik ve dehidratasyon bulgularina kontrol grubuna oranla daha sık rastlandığı görülmektedir. R/A AP olan hastalarm \%45,8'inde 3 bulgu (diare+kusma+ateş) bir arada görülürken diare+kusma hastaların \%13,8'inde, diare+ateş ise $\% 15,2$ 'sinde görüldü.

Hastaların \%97,7'sine hastaneye başvuru sonrasında probiyotik başlanmış, diare nedeniyle hastaların \%56,7'sinde bakteriyel nedenler düşünülerek antibiyotik başlanmıştır. R/A saptanan hastaların \%100'ünde probiyotik kullanılmış olup istatistiksel olarak anlamlı bulunmamıștır. R/A saptanan hastaların \%34,7'si antibiyoterapi almış olup \%25'i 3 gündür süren ateş sonrası hastaneye başvurduğundan henüz antijen pozitifliği saptanmadan antibiyoterapi başlanıp R/A AP saptanınca antibiyoterapi kesilmiş, \%9,7'sinde ise eşlik eden hastalık veya süperenfeksiyon nedeniyle antibiyoterapi ihtiyacı olmuştur. Hastaların \%15,3'ünde eşlik eden hastalıklar varken R/A saptanan hastaların \%4,4'ünde eşlik eden hastalık mevcuttu.

Yatış gün sayısına bakıldığında en kısa 1 en uzun 12 gün olarak gözlenmiş olup ortalama 2.96 gündür. R/A AP saptanan hastalar en kisa 1 en uzun 12 gün yatırılmış olup ortalama 3.61 ( \pm 2.01) iken kontrol grubunda ortalama 2.77 ( \pm 1.66$)$ olarak saptandı. R/A AP saptanan hastaların diğer hastalardan ortalama 1 gün daha fazla yattığı gözlendi.
R/A AP saptanan grup ve kontrol grup arasında CRP, hematolojik ve biyokimyasal parametreler arasında istatistiksel olarak anlamlı fark saptanmasa da beyaz küre ve nötrofil kontrol grubunda daha yüksek bulunurken, lenfosit, üre ve AST (aspartat transaminaz)-ALT (alanin transaminaz) R/A AP saptanan grupta hafif daha yüksek bulunmuştur (Tablo 1).

İki grupta da hastaların hiçbirinde mortalite veya morbidite saptanmamış, hastaların tümü şifa ile externe edilmiştir.

\section{TARTIŞMA}

Çok sayıda infeksiyöz etken gastroenterite yol açmakta olup koruyucu önlemlerinin arttırılması ile parazit ve bakterilere bağlı gastroenteritlerde azalma sağlanabilirken, viral gastroenteritlerin sıklı̆ğ azaltılamamıştır6. Bütün gastroenterit etkenlerini saptayabilecek laboratuvar testleri olmadığından tanıda olası etkenden şüphelenmek ve ona yönelik spesifik testler yapmak önem arzetmektedir ${ }^{7}$. Bu çalışma ile en sık görülen iki viral neden olan Rotavirüs ve Enterik Adenovirüs'ün sıklığının saptanması, epidemiyolojik faktörler, klinik bulgu ve laboratuvar paramatreleri ile bu etkenleri düşündürecek bulguların saptanması amaçlanmıştır.

Rotavirus enfeksiyonu 1-3 günlük inkübasyon periyodunun ardından ateş ve kusma sonrasinda sulu diare ile karakterize bir klinik tabloya neden olur. Diğer viral etkenlerden daha ağır bir gastroenterite yol açar8. Esas olarak fekal oral yolla bulaşır. Çocukların hemen hemen hepsi ilk 5 yaş içinde rotavirüsle enfekte olur ${ }^{9}$. Ancak özellikle 2 yaş altında daha ağır bir klinik tabloya neden olmaktadır. Mortalite ve morbiditeden dehidratasyon, elektrolit dengesizlikleri ve asidoz sorumludur?. 
Tablo I: Laboratuvar parametrelerinin değerlendirilmesi

\begin{tabular}{|c|c|c|c|c|c|c|}
\hline & Grup & En düşük & En yüksek & Ortalama & SD & P değeri \\
\hline \multirow{2}{*}{$\begin{array}{l}\text { Beyaz küre } \\
(\mathrm{K} / \mu \mathrm{L})\end{array}$} & Kontrol & 2,53 & 45,90 & 12,208 & 5,91 & \multirow{2}{*}{0.395} \\
\hline & R/A pozitif & 3,26 & 26,59 & 11,249 & 4,85 & \\
\hline \multirow{2}{*}{$\begin{array}{l}\text { Hemoglobin } \\
\text { (g/d) }\end{array}$} & Kontrol & 7,0 & 15,2 & 11,5 & 6,04 & \multirow{2}{*}{0.953} \\
\hline & R/A pozitif & 8,1 & 14,5 & 11,6 & 1,16 & \\
\hline \multirow{2}{*}{$\begin{array}{l}\text { Platelet } \\
(\mathrm{K} / \mu \mathrm{L})\end{array}$} & Kontrol & 70 & 978 & 380.000 & 137,9 & \multirow{2}{*}{0.240} \\
\hline & R/A pozitif & 120 & 785 & 385.000 & 148,9 & \\
\hline \multirow{2}{*}{$\begin{array}{l}\text { Nötrofil } \\
(\mathrm{K} / \mu \mathrm{L})\end{array}$} & Kontrol & 0,30 & 39,56 & 6,11 & 4,91 & \multirow{2}{*}{0.240} \\
\hline & R/A pozitif & 0,41 & 14,32 & 4,92 & 3,01 & \\
\hline \multirow{2}{*}{$\begin{array}{l}\text { Lenfosit } \\
(\mathrm{K} / \mu \mathrm{L})\end{array}$} & Kontrol & 0,6 & 20,8 & 4,8 & 2,8 & \multirow{2}{*}{0.388} \\
\hline & R/A pozitif & 0,9 & 17,6 & 5,2 & 3,1 & \\
\hline \multirow{2}{*}{$\begin{array}{l}\text { Eozinofil } \\
(\mathrm{K} / \mu \mathrm{L})\end{array}$} & Kontrol & 0,01 & 1,69 & 0,13 & 0,22 & \multirow{2}{*}{0.097} \\
\hline & R/A pozitif & 0,01 & 1,33 & 0,13 & 0,22 & \\
\hline \multirow{2}{*}{$\begin{array}{l}\text { Bazofil } \\
(\mathrm{K} / \mu \mathrm{L})\end{array}$} & Kontrol & 0,01 & 0,14 & 0,03 & 0,02 & \multirow{2}{*}{0.205} \\
\hline & R/A pozitif & 0,01 & 0,21 & 0,04 & 0,03 & \\
\hline \multirow{2}{*}{$\begin{array}{l}\text { Glukoz } \\
(\mathrm{mg} / \mathrm{dl})\end{array}$} & Kontrol & 44 & 161 & 84 & 19,3 & \multirow{2}{*}{0.298} \\
\hline & R/A pozitif & 45 & 118 & 78 & 14,9 & \\
\hline \multirow{2}{*}{$\begin{array}{l}\text { Üre } \\
(\mathrm{mg} / \mathrm{dl})\end{array}$} & Kontrol & 4,2 & 58,7 & 20,59 & 9,59 & \multirow{2}{*}{0.064} \\
\hline & R/A pozitif & 3,9 & 155,2 & 22,7 & 18,4 & \\
\hline \multirow{2}{*}{$\begin{array}{l}\text { Kreatinin } \\
(\mathrm{mg} / \mathrm{dl})\end{array}$} & Kontrol & 0,31 & 0,81 & 0,43 & 0,07 & \multirow{2}{*}{0.418} \\
\hline & R/A pozitif & 0,31 & 0,99 & 0,43 & 0,08 & \\
\hline \multirow{2}{*}{$\begin{array}{l}\text { Total protein } \\
\text { (gr/dl) }\end{array}$} & Kontrol & 3,39 & 8,15 & 6,46 & 0,60 & \multirow{2}{*}{0.264} \\
\hline & R/A pozitif & 5,38 & 7,82 & 6,44 & 0,56 & \\
\hline \multirow{2}{*}{$\begin{array}{l}\text { Albumin } \\
\text { (gr/dl) }\end{array}$} & Kontrol & 1,7 & 5,1 & 4,19 & 0,43 & \multirow{2}{*}{0.152} \\
\hline & R/A pozitif & 3,3 & 4,9 & 4,19 & 0,38 & \\
\hline \multirow{2}{*}{$\begin{array}{l}\text { ALT } \\
(U / L)\end{array}$} & Kontrol & 6 & 129 & 21,8 & 13,9 & \multirow{2}{*}{0.360} \\
\hline & R/A pozitif & 7 & 97 & 27,22 & 14,8 & \\
\hline AST & Kontrol & 12 & 338 & 40,86 & 23,62 & 1 \\
\hline$(\mathrm{U} / \mathrm{L})$ & R/A pozitif & 22 & 78 & 45,63 & 12,75 & 0.070 \\
\hline Sodyum & Kontrol & 127 & 148 & 137,2 & 3,07 & 0 \\
\hline$(\mathrm{mmol} / \mathrm{L})$ & R/A pozitif & 130 & 160 & 138,4 & 4,15 & 0.504 \\
\hline Potasyum & Kontrol & 2,71 & 6,20 & 4,22 & 0,60 & 0 \\
\hline$(\mathrm{mmol} / \mathrm{L})$ & $\mathrm{R} / \mathrm{A}$ pozitif & 3,08 & 6,01 & 4,28 & 0,55 & 0.300 \\
\hline Kalsiyum & Kontrol & 5,6 & 11,1 & 9,3 & 0,66 & 023 \\
\hline$(\mathrm{mg} / \mathrm{dl})$ & R/A pozitif & 7,7 & 11,1 & 9,4 & 0,57 & 0.254 \\
\hline Klor & Kontrol & 94 & 126 & 105,9 & 3,96 & \\
\hline$(\mathrm{mmol} / \mathrm{L})$ & R/A pozitif & 97 & 134 & 107,9 & 5,5 & 0.107 \\
\hline CRP & Kontrol & 0,8 & 256,2 & 9,45 & 22,4 & 0150 \\
\hline (mg/dl) & R/A pozitif & 0,7 & 159 & 9,52 & 18,2 & \\
\hline
\end{tabular}

ALT; Alanin transaminaz, AST; Aspartat transaminaz, CRP; C-reaktif protein, SD; standart deviasyon 
Enterik adenovirüs ise rotavirüsden sonra en sık saptanan akut viral gastroenterit etkenidir ${ }^{10}$.

Türkiye'de yapılan çalışmalarda Rotavirüs enfeksiyon sıklığl \%20-53 arasında bildirilmiştir11-13 Bizim çalışmamızda \%18,4 oranında rotavirüs antijen pozitifliği saptanmış olup literatürlerden daha düşük olduğu gözlenmiştir.

Enterik adenovirüs çocukluk yaş grubunda \%123,7 arasında, beş yaş altında ise \%2,3-17 arasında değişmektedir ${ }^{14-16}$. Bizim çalışmamızda $\% 2,0$ oranında Enterik Adenovirüs AP saptanmış olup Türkiye'den bildirilen oranlara yakın olarak saptanmıştır.

Çalışmamızda kız çocuklarının \%19,2'sinde, erkek çocuklarının \%21,2'sinde R/A AP saptanmıştır. Ülkemizde yapılan diğer çalışmalarla uyumlu olarak erkek ve kız çocuklarda AP açısından istatistiksel olarak anlamlı bir fark bulunamamıştır6.

Hem Türkiye'deki çalışmalarda hem dünya genelinde yapılan çalışmalarda Rotavirüs sıklığının 6-24 ay aralığında artış gösterdiği 6,17 , Enterik Adenovirüs sıklığının ise 0-36 ay aralığında artış gösterdiği bildirilmiştir5. Çalışmamızda gastroenteriti olan hasta sayısının 0-24 ay arasında belirgin yüksek olduğu görülmektedir. Hastaların \%56,9'unun, R/A AP olanların \%40'ının 6-24 ay aralığında olduğu görülmekte olup literatür verileri ile uyumludur.

Ilıman iklimlerde rotavirus enfeksiyonları kış aylarında pik yaparken tropikal iklime sahip ülkelerde ise enfeksiyon tüm yıla yayılmıștır9 . Türkiye'de yapılan çalışmalarda çeşitli aylarda sıklığın arttığını gösteren çalışmalar olsa da daha çok kış aylarında viral gastroenterit sıklığının $\quad$ arttığı bildirilmiştir ${ }^{12,18,19}$. Çalışmamızda ise tüm gastroenteritlere kış aylarında daha sık rastlansa da istatistiksel olarak anlamlı bulunmamıştır.
Yapılan çalışmalarda gaita sayısının R/A gastroenteritlerinde arttığl belirtilmiștir ${ }^{20,21}$. Çalışmamızda literatürle uyumlu olarak R/A AP saptanan hastaların $\% 80,6$ 'sında 10 ve üzeri olduğu ve bunun istatistiksel olarak anlamlı olduğu görülmüştür.

Çocuklarda rotavirus gastroenteriti geniş bir klinik spektrumda gözlenebilir. Asemptomatik olabileceği gibi dehidratasyon ile seyreden ciddi diareye de neden olabilir. Genellikle önce kusma ile başlar. Kusmayı ishal ve dehidratasyon takip eder, ateş ve karın ağrısı da sık görülen bulgulardandır ${ }^{17}$. Staat ve arkadaşları yaptıkları çalışmada hastaların \%56'sında diare, kusma ve ateşin bir arada görüldügünü, hastaların \%38'inde diare ve kusma, \%19'unda diare ve ateş görüldügünü belirtilmişler ${ }^{22}$. Bizim çalışmamızda R/A AP olan hastaların \%45,8'inde 3 bulgu (diare+kusma+ateş) bir arada görülürken diare+kusma hastaların \%13,8'inde, diare+ateș ise $\% 15,2$ 'sinde görüldü. Hastalarımızın klinik bulgularını değerlendirdiğimizde R/A AP grubunda gaita sayısının yüksek olduğu, iștahsızlık, halsizlik ve dehidratasyonun istatistiksel olarak anlamlı yüksek saptandı̆̆ı, dehidratasyonun özellikle 6-24 ay grubunda yüksek olduğu gözlenmiştir.

Albano ve arkadaşlarının yaptığı çalışmada yatış gün sayısı R/A saptanan hastalarda daha yüksek bulunmuştur ${ }^{23}$. Ancak bizim çalışmamızda yatış gün sayısını kontrol grubuna göre biraz yüksek bulunsa da istatistiksel olarak anlamlı bulunmamıștır. Bu durumun kliniğimizde yatak sayısının az olması nedeniyle hemodinamik açıdan stabil hastaların erken taburcu olmasıyla ilgili olduğunu düşündük.

Kliniğimize diare ve uzun süren ( $>72$ saat) ateş nedeniyle başvuran hastalara antibiyoterapi başlandığından hastaların antijen sonuçları beklenirken R/A AP olan hastaların \%25'ine gereksiz antibiyotik verilmiştir. $\mathrm{Bu}$ durumda göstermektedir ki viral gastroenteritler 
düşündürecek epidemiyolojik ve klinik bulguların saptanması gereksiz antibiyoterapi kullanımını ciddi oranda azaltacaktır. Bu nedenle daha geniş çalışmaların yapılması önem arz etmektedir.

Qadori ve arkadaşlarının gastroenteritlerde sodyum, potasyum, üre, kreatinin ve glukozun değerlendirildiği çalışmada gastroenterilerde hipoglisemi dişında major elektrolit bozukluğu saptamadıklarını belirtmişlerdir ${ }^{24}$. Çubuk ve arkadaşlarının yaptığı çalışmada CRP, hematolojik ve biyokimyasal parametreler arasında anlamlı farklılık saptanmamıştır ${ }^{20}$. Bizim çalışmamızda laboratuvar parametrelerine bakıldığında kontrol grubu ve R/A AP saptanan grup arasinda hemoglobin, platelet, eozinofil, bazofil, glukoz, kreatinin, total protein, albumin, sodyum, potasyum, kalsiyum, klor ve CRP arasinda fark bulunmamıștır. Beyaz küre ve nötrofil kontrol grubunda daha yüksek bulunurken, lenfosit, üre ve AST (aspartat aminotransaminaz)-ALT (alanin aminotransaminaz) R/A AP saptanan grupta hafif daha yüksek bulunmuştur ancak istatistiksel olarak anlamlı bulunmamıştır.

\section{SONUÇ}

Çalışma sonuçları göz önüne alındığında R/A bağlı gastroenteritlerde klinik bulguların daha belirgin olduğu, ancak laboratuvar parametrelerinden anlamlı farklılık olmadığı gözlenmektedir. $\mathrm{Bu}$ nedenle özellikle klinik bulguları daha ağır olan gastroenterit hastalarında viral nedenlerin araştırılması etkin semptomatik tedavi ve gereksiz antibiyoterapiden kaçınılmasını sağlayacaktır.

Çıkar Çatışması Beyanı: Yazarlar çıkar çatışması olmadığını bildirmişlerdir.

Finansal Destek: Bu çalışma her hangi bir fon tarafından desteklenmemiștir.

Declaration of Conflicting Interests: The authors declare that they have no conflict of interest.
Financial Disclosure: No financial support was received.

\section{KAYNAKLAR}

1. Parashar UD, Burton A, Lanata C, et al. Global mortality associated with rotavirus disease among children in 2004. J Infect Dis. 2009; 200 Suppl 1: 9-15.

2. Kocabaş E, Timurtaş Dayar G. Rotavirüs aşıları. J Pediatr Inf. 2015; 9: 166-74.

3. Santos N, Hoshino Y. Global distribution of rotavirus serotypes/genotypes and its implication for the development and implementation of an effective rotavirus vaccine. Rev Med Virol. 2005; 15: 29-56.

4. Köksal AO, Köksal T. Ankara'da ebeveynlerin rotavirüs hakkında bilgi düzeyleri ve çocukların rotavirüs aşllanma oranları. Gaziantep Med J. 2012; 18: 151-4.

5. Bass DM. Rotavirus and other agents of viral gastroenteritis. Behrman RE, Kliegman RM, Jenson HB (eds) Nelson Textbook of Pediatrics, 17thed. Philedelphia: WB Saunders Co., 2004: 1081-3.

6. Doğan Y, Ekși F, Karslıgil T, Bayram A. Akut gastroenteritli hastalarda rotavirüs ve adenovirüs varlığının araștırılması. Türk Mikrobiyol Cem Derg. 2014; 44: 18-22 doi:10.5222/TMCD.2014.018.

7. Elliott EJ. Acute gastroenteritis in children. BMJ. 2007; 334: $35-40$.

8. Staat MA, McNeal MM, Bernstein DI. Rotaviruses. In "Textbook of Pediatric Infectious Diseases". Cherry JD, Harrison GJ, Kaplan SL, Steinbach WJ, Hotez PJ (eds). 7th ed. Philadelphia, Saunders. 2014; 2176-92.

9. Glass RI, Parashar U, Patel M, Gentsch J, Jiang B. Rotavirus vaccines: Successes and challenges. J Infect. 2014; 68 Suppl 1: 9-18.

10. Kurugol Z, Devrim İ. Gastroenteritler. Çocuk Enfeksiyon Dergisi. 2014; 8: 71-81.

11. Ceyhan M, Alhan E, Salman N, et al. Multicenter prospective study on the burden of rotavirus gastroenteritis in Turkey, 2005-2006: a hospital-based study. J Infect Dis. 2009; 200 (Suppl 1): 234-8.

12. Karadag A, Acikgoz ZC, Avci Z, et al. Childhood diarrhoea in Ankara, Turkey:epidemiological and clinical features of rotavirus-positive versus rotavirusnegative cases. Scand J Infect Dis. 2005; 37: 269 -75.

13. Biçer S, Şahin GT, Koncay B, et al. Çocuk acil servisinde saptanan rotavirus gastroenteriti olgularının sıklığı. Çocuk Enfeksiyon Derg. 2008; 2: 96-9. 
14. Tekin A. Mardin'deki akut gastroenteritli çocuklarda rotavirüs ve enterik adenovirüs sıklığı. J Clin Exp Invest. 2010; 1: 41-5.

15. Celik C, Gozel MG, Turkay H, et al. Rotavirus and adenovirus gastroenteritis: time series analysis. Pediatr Int. 2015; 57: 590-6.

16. Güreser AS, Karasartova D, Taş̧̧ı L, Boyacıoğlu ZI, Taylan Özkan HA. Çorum'da Akut Gastroenteritli Çocuklarda Rotavirüs ve Adenovirüs Saptanma Sıklığı. Flora. 2017; 22: 58-66 doi: 10.5578/flora.61876.

17. Dennehy PH, Cortese MM, Begue RE. A case-control study to determine risk factors for hospitalization for rotavirus gastroenteritis in US children. Pediatr Infect Dis J. 2006; 25: 1123-31.

18. Kurugöl Z, Geylani S, Karaca Y, et al. Rotavirius gastroen $\neg$ teritis among children under five years of age in İzmir, Turkey. Turk J Pediatr. 2003; 45: 290-4.

19. Yasa O, Ergüven M, Karaca Atakan S, ve ark. Yatarak izlenen rotavirüs vakalarımızın epidemiyolojik özellikleri ve nozokomiyal infeksiyon. Çocuk Dergisi. 2009; 9: 127-30.
20. Çubuk E, Aktar F, Yılmaz K, et al. 2011-2015 Yllları Arasında Üniversitemiz Çocuk Polikliniklerine Ishal Şikâyeti Ile Başvuran ve Adenovirüs ve/veya Rotavirüs Pozitifliği Saptanan Hastaların Retrospektif Değerlendirilmesi. Van Tıp Derg. 2008; 25: 374-80. DOI: $10.5505 /$ vtd.2018.38802.

21. Coffin SE, Elser J, Marchant C, et al. Impact of acute rotavirus gastroenteritis on pediatric outpatient practices in the United States. Pediatr Infect Dis J. 2006; 25: $584-9$.

22. Staat MA, Azimi $P$, Berke $T$, et al. Clinical presentations of rotavirus infection among hospitalized children. Pediatr Infect Dis J. 2002 Mar; 21: 221-7.

23. Albano F, Bruzzese E, Bella A, et al. Rotavirus and not age determines gastroenteritis severity in children: a hospital-based study. Eur J Pediatr. 2007; 166: 241-7.

24. Qadori M, Flem E, Bekkevold T, et al. Hypoglycaemia was common in acute gastroenteritis in a prospective hospital-based study, but electrolyte imbalances were not. Acta Paediatr. 2018 Aug; 107: 1455-60. doi: 10.1111/apa.14318. 